\title{
Factors Affecting Implementation of Reporting Online Hospital Information Systems Second District Kediri
}

\author{
Ikke Winar Rachmawaty, \\ Yuly Peristiowati, Novita \\ Ana Anggraini
}

Master Program of Public Health, Institute of Health Sciences Strada Indonesia

Email:

kessus.kabkediri@gmail.com

Received: October 5, 2020

Accepted: November 25, 2020

Published : November 30, 2020

\begin{abstract}
The need for data and information is currently growing very rapidly both in quantity and quality. With the enactment of Law Number 14 Year 2008 regarding Openness of Public Information (KIP), the availability of data and information is needed by the public. The data and information every year changes with the times, including the Hospital Information System (SIRS). The purpose of this study was to analyze the Factors Influencing the Implementation of Online SIRS in Hospitals in the District of Kediri. The design of this study was an observational quantitative study with a cross section approach with the focus of the research directed to be analyzing the Factors Influencing the Implementation of Online SIRS in Hospitals in the District of Kediri with a sample of 166 respondents taken with the Simple Random Sampling technique. The findings found that the majority of respondents had moderate motivation as many as 91 respondents $(54.8 \%)$. Most respondents have knowledge in the medium category of 112 respondents (67.4\%). Most respondents had a high category reward of 93 respondents (56.1\%). Most respondents had a discrepancy with the sanctions provided by 88 respondents (56.3\%). Most respondents lacked in conducting SIRS Online reports as many as 141 respondents $(85.3 \%)$. The results of the study using the Logistic Regression Test showed that the most influential variable with a p-value of $0.006<0.05$ then $\mathrm{H} 0$ was rejected and $\mathrm{H} 1$ was accepted so it was concluded that there was a significant effect on the motivation of officers on the implementation of SIRS online at Hospitals in Kediri Regency . The effectiveness of implementing SIRS Online in hospitals can be influenced by the motivation of officers in implementing SIRS Online, the knowledge of officers in carrying out SIRS Online, rewards and sanctions received by officers. However, to be more effective in order to increase the motivation of officers to be willing to do SIRS Online reporting routinely and correctly.
\end{abstract}

Keywords: Motivation, knowledge, reward, sanctions, SIRS

Copyright (C) 2020 IIK STRADA Indonesia All right reserved.

This is an open-acces article distributed under the terms of the Creative Commons Attribution-ShareAlike 4.0 International License. 


\section{BACKGROUND}

The need for data and information is currently growing very rapidly both in quantity and quality. With the enactment of Law Number 14 Year 2008 regarding Openness of Public Information (KIP), the availability of data and information is needed by the public. The data and information every year changes with the times, including the Hospital Information System (SIRS) (Ministry of Health, 2011).

Hospital Information System (SIRS) is an arrangement that deals with data collection, data management, information presentation, analysis and inference of information as well as the delivery of information needed for hospital activities. Hospital information systems include: clinical information systems, administrative information systems and management information systems. Hospital Information System (SIRS) covers all public and specialized hospitals. The hospital is managed by both public and private. Enforcement of SIRS is regulated in Law of the Republic of Indonesia Number 44 Year 2009 concerning Hospitals, and Regulation of the Minister of Health of the Republic of Indonesia Number 1171 / Menkes / Per / VI / 2011 concerning Hospital Information System dated June 15, 2011 and was promulgated on July 1, 2011 in Jakarta (Ministry of Health, 2011).

Hospitals make various efforts to provide higher quality services to patients, so that many hospitals (hospitals) adopt information systems (SI). SI supports the clinical workflow in various ways, which in turn contributes to better patient care. The main mission carried by SIRS is to provide information, especially about patients, in a correct, relevant and renewable way, accessed by parties (individuals or institutions) in a format that can be used. SIRS must be able to act as a means of quality communication between actors in hospitals and related external parties, such as government agencies (Snimed, 2015).

SIRS Reporting as referred to in Republic of Indonesia Minister of Health Regulation No. 1171 / MENKES / PER / VI / 2011 consists of 5 (five) Report Recapitulation (RL), namely: RL 1 contains Basic Data, service indicators, and hospital bed facilities. The data is reported at any time if there is a change in the basic data from the hospital, so this data is data that is renewable at any time (updated). RL 2 contains Personnel Data which is reported periodically every year. RL 3 contains Hospital Service Activity Data that is reported periodically every year. RL 4 contains Patient Morbidity / Mortality Data which is reported periodically every year. RL 5 is Monthly Data that is reported periodically every month, containing visit data and data of 10 (ten) major diseases (Ministry of Health, 2011).

Kediri Regency has 10 hospitals, both government and private. Not all of these hospitals carry out maximum SIRS reporting, and even tend to decrease over time. The trend of reporting SIRS on line for all hospitals in Kediri Regency for the past four years is shown in Figure 1.

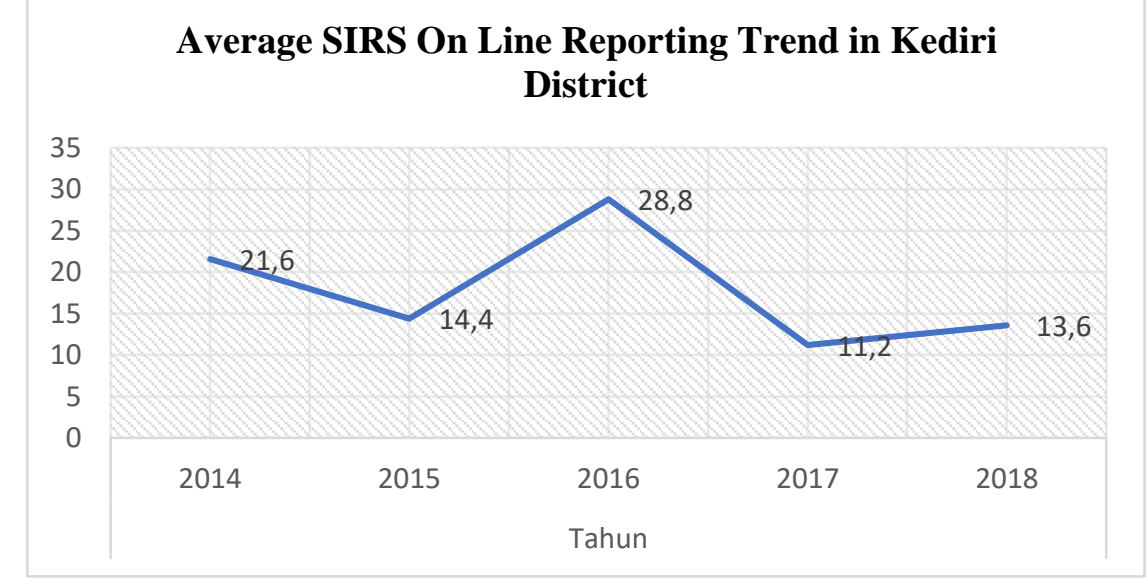

Figure 1

SIRS Reporting Trend in Kediri Regency

Source: Ministry of Health's online SIRS report, 2014

From Figure 1.1 it can be seen that on-line SIRS reporting conducted by hospitals in Kediri Regency on average does not reach 50\%. Reporting of SIRS on line hospitals in Kediri Regency during the past four years was highest in 2016, amounting to $28.8 \%$. This situation is still far from the expected SIRS reporting. From these averages it can be estimated that there are a number of hospitals 
that have not reported SIRS online. Some things that might be the cause of the not yet running online SIRS reporting is the lack of understanding of hospital managers about the benefits of SIRS reporting for the hospital itself and for the general public. Another factor that may be related to SIRS reporting is the availability of reporting personnel both in qualifications and in number. Possible alternative solutions to problems are increasing the frequency of workshops/ training on the benefits and application of SIRS on line aimed at hospital managers and prospective SIRS operators.

Globally, there is also an overview of Hospital Information System Management Report (SIRS) in the SIRS reporting trend in Kediri Regency based on the hospital group as illustrated in Figure 2.

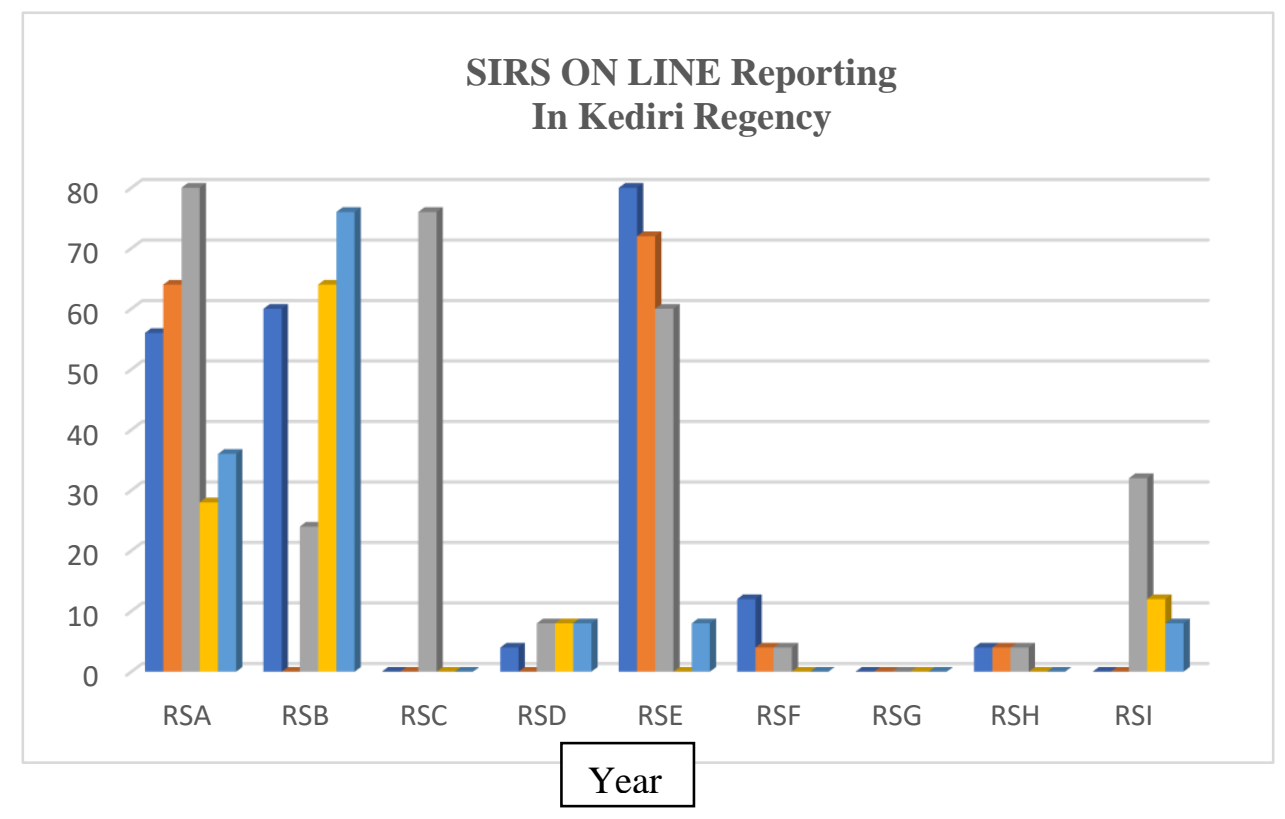

Figure 2

SIRS Reporting Trend in Kediri Regency Based on Hospital Groups

Source: Ministry of Health's online SIRS report, 2019

From the results of a preliminary survey that has been carried out by researchers, it is obtained data that the competent authority has annually provided guidance to the hospital. Coaching is done through an online SIRS report processing meeting with the General Allocation Fund (DAU) budget every year. In reality, efforts by the government have not been maximized by hospitals to improve their SIRS reports. Other data shows that most hospitals complain that there are too many types of reports that need to be done, there is no system of rewards or administrative sanctions from the Ministry of Health for those who do not work, nor is there support from superiors in the work of SIRS.

From the background description above, the researcher wants to analyze what factors influence the implementation of SIRS Online Hospital in Kediri.

\section{METHODS}

In this study, researchers used a quantitative analytic design with a cross sectional approach which is a study to study the dynamics of the correlation between risk factors and effects, by way of approach, observation or data collection at a time (point time approach), that is, each subject the study was only observed once and measurements were made on the character status or subject variables at the time of examination. This does not mean that all research subjects were observed at the same time (Soekidjo, 2012). This study will analyze the effect of motivation, knowledge, reward and sanctions on the implementation of online sirs reports at Hospitals in Kediri Regency.

Total population of 284 respondents and a sample of 166 respondents taken by Proportional Stratified Random Sampling. Analysis of data using the Logistic Regression test.

\section{RESULT}

Table 1 Results of statistical tests of factors affecting the implementation of online SIRS at Hospitals in Kediri Regency conducted on August 5 - October 30, 2019 with 166 respondents 


\begin{tabular}{ccccc}
\hline Variabel & $\alpha$ & $R^{2}$ & Sig & $\operatorname{Ex}(\mathrm{B})$ \\
\hline Motivation & & & 0.007 & 1.190 \\
Knowlage & \multirow{2}{*}{0,05} & 0,024 & 0.006 & 0.810 \\
Reward & & & 0.023 & 0.929 \\
Sanksi & & & 0.016 & 0.595 \\
\hline
\end{tabular}

\section{Statistic}

a. Motivation for SIRS Online Reporting

Based on the results of the Logistic Regression analysis of motivational variables on utilization shows that sig value of $0.007<0.05$ then $\mathrm{H} 0$ is rejected and $\mathrm{H} 1$ is accepted so it is concluded that there is an influence of officer motivation on the implementation of SIRS online at Hospitals in Kediri Regency.

b. Knowledge of SIRS Online Reporting

Based on the results of the Logistic Regression analysis of knowledge variables on utilization shows that a sig value of $0.006<0.05$ then $\mathrm{H} 0$ is rejected and $\mathrm{H} 1$ is accepted so it is concluded that there is an influence of officers' knowledge on the online SIRS implementation at the Kediri Regency Hospital.

c. Reward for SIRS Online Reporting

Based on the results of the Logistic Regression analysis the reward variable for utilization shows that a sig value of $0.023<0.05$ then $\mathrm{H} 0$ is rejected and $\mathrm{H} 1$ is accepted so it is concluded that there is an effect of the employee reward on the implementation of SIRS online at the Kediri Regency Hospital.

d. Sanctions against SIRS Online Reporting

Based on the results of the Logistic Regression analysis the sanctions variable towards utilization shows that a sig value of $0.016<0.05$ then $\mathrm{H} 0$ is rejected and $\mathrm{H} 1$ is accepted so it is concluded that there is an effect of the officer sanctions on the implementation of SIRS online at the Kediri Regency Hospital.

\section{Odds Ratio}

a. Highly motivated respondents have the possibility of reporting SIRS Online well as much as $119 \%$.

b. Respondents with high knowledge have the possibility to report SIRS Online well as much as $81 \%$

c. Respondents with high rewards have the possibility of reporting SIRS Online well as well as 92.9\%.

d. Respondents with appropriate sanctions have the possibility of reporting SIRS Online well as much as $59.5 \%$.

e. Based on the interpretation of the data above, the most influential factor is motivation with a value of $119 \%$ on the work of the SIRS Online report.

\section{DISCUSION}

\section{Staff Motivation in Working Online SIRS Report in Hospitals in the District of Kediri}

The results showed that the majority of respondents had moderate motivation as many as 91 respondents (54.8\%). In addition, 48 respondents (28.9\%) had low motivation categories. Whereas 27 respondents (16.3\%) had high motivation categories.

According to researchers motivation is a determination to do something, so that if the person has high motivation then that person will try to actively do something. However, it is different if someone has a low motivation, where the person will tend to just follow the course and not try to do something routinely. Based on the results of the study it was found that there are only a small proportion who have high motivation to implement SIRS Online well. Whereas those who have low motivation are more than those who have high motivation where it is because the officers do not 
understand the importance of implementing SIRS Online, even though SIRS Online itself if implemented optimally can be beneficial for both hospitals and for patients.

\section{Officers' Knowledge in Working Online SIRS Reports at Hospitals in Kediri Regency}

The results showed that most respondents had knowledge in the medium category of 112 respondents (67.4\%). In addition, a number of 39 respondents $(23.5 \%)$ had knowledge in the high category. Whereas 7 respondents $(4.2 \%)$ had knowledge in the low category.

According to researchers, knowledge of a person will shape one's behavior. Where if knowledge is good then the things he does will be directed and clear. If knowledge is lacking, the things he does tend to be undirected and careless without knowing the pros and cons of that. Based on the results of the study found that there are still some respondents who have low knowledge about SIRS Online. This lack of knowledge is caused by the lack of information obtained on how to operate SIRS Online, as well as the benefits and functions of SIRS Online for hospitals, staff and the public. SIRS itself serves to help realize the vision and mission of the Hospital, Build and develop information technology infrastructure, Socialize and improve the ability of hospital human resources to operate information technology, Improve the performance of the Hospital to be more efficient and effective, Increase the sale value of the Hospital in the community as Hospitals that prioritize services, Data management becomes fast and appropriate information for the benefit of Users, Management and Government, Improve quality and speed up the Hospital service process, Increase employee loyalty and pride in the Hospital where they serve, Reducing the errors of factors human, Eliminating the problem of data redundancy, Eliminating the problem of data inconsistency, Mapping the design of information systems in accordance with current and future information needs.

\section{Officer Reward in Working on Online SIRS Reports at Hospitals in Kediri Regency}

The results showed that most respondents had high reward categories of 93 respondents (56.1\%). Whereas 72 respondents $(43.9 \%)$ had low category rewards.

According to researchers reward is something that we give to someone because he did something. That something is reasonable as an appreciation, as an expression of our gratitude and attention that he has done a good job. Reward can also be obtained depending on the policy of the leadership, if the leadership of an institution can appreciate the activities carried out by its members, the reward will be easily obtained by officers, but conversely if the leader does not appreciate the activities carried out by members it will be very difficult to get a reward. Based on the results of the study it was found that there are still many respondents who are still low in getting rewards where it is caused by officers who often implement SIRS Online compared to those who rarely implement SIRS Online are equally lacking in appreciation. Where it is also caused by the high expectations desired by the leadership where the leadership felt that the officers in implementing SIRS Online were still lacking.

\section{Sanctions for Hospitals Not Working on Online SIRS Reports in Hospitals in Kediri Regency}

The results showed that the majority of respondents had a discrepancy with the sanctions of 88 respondents (56.3\%). Whereas 78 respondents $(43.7 \%)$ had compatibility with sanctions.

According to researchers the existence of sanctions to be urgent because the aim is to reeducate someone to be able to adjust to their environment. Enforcement of sanctions for hospital owners / employees / officers who do not work on the SIRS online report is also constrained by the absence of standard rules for sanctions applied in the Minister of Health regulations. This will always be a problem in terms of enforcement and be a reason if someone still does not work on SIRS reports online. Based on the results of the study it was found that most said there were discrepancies in sanctions. Where after being sanctioned, some respondents still did not apply online SIRS because sanctions were only given a warning.

\section{Online SIRS Reporting at Hospitals in Kediri District}

The results showed that the majority of respondents lacked in conducting SIRS Online reports as many as 95 respondents (57.2\%). In addition, 71 respondents (42.8\%) had done the SIRS Online report well. Whereas based on the research of the Ministry of Health of the Republic of Indonesia (2018) states that the SIRS Online Achievement figure in Kediri Regency is an average value of 
$13.6 \%$ from a total of 10 hospitals, where the highest achievement is in Toeloengrejo Hospital with a value of $76 \%$, while the smallest achievement is there are at Amelia Hospital, Wilujeng Hospital, Aura Shifa Hospital, Arga Husada Hospital and Permata Hati Mother and Child Hospital with a value of $0 \%$.

According to researchers implementing SIRS Online reporting can be of great benefit to hospitals and to patients and the community. Where the holding of SIRS Online can improve the performance of hospitals to be more efficient and effective, increase the sale value of hospitals in the community as hospitals that prioritize services, improve quality and speed up the process of hospital services, increase employee loyalty and pride in the hospitals where they serve , Reducing mistakes human factors. Based on the results of the study, it was found that the majority of respondents lacked in reporting SIRS Online. Where it is caused due to lack of knowledge and motivation of respondents.

Based on the results of the study it was found that there are still many hospitals in Kediri that have identified low SIRS achievements. The low achievement of SIRS Online in Kediri Regency is due to the fact that many hospitals in Kediri Regency use private-made SIRS Online applications where the application is incompatible with SIRS provided by the government so that much data cannot be read by the SIM-RS. It is hoped that hospitals in Kediri Regency can replace SIRS Online from the private sector with SIM-RS from the government so that data can be monitored properly.

\section{The Influence of Officers' Motivation on Online SIRS Reporting at Hospitals in Kediri Regency.}

Based on the results of the Logistic Regression analysis of motivational variables on utilization shows that a p-value of $0.007<0.05$ then $\mathrm{H} 0$ is rejected and $\mathrm{H} 1$ is accepted so it is concluded that there is an influence of staff motivation on the implementation of SIRS online at Hospitals in Kediri Regency. Whereas based on the cross tabulation data it was found that almost half of respondents who had the motivation of the category were doing SIRS Online reporting with less categories as many as 49 respondents $(29.5 \%)$. Based on the results of the Odds Ratio test it was found that respondents with high motivation had the possibility of reporting SIRS Online well as well as $119 \%$.

According to researchers, there is a high level of motivation in carrying out a very important activity where someone who has high motivation will tend to be better at doing things. In this case the motivation of officers to implement SIRS Online reporting. Someone who has high motivation tends to implement well, whereas officers who have low motivation tend to implement SIRS Online less. So therefore it can be concluded that there is an influence of staff motivation on the implementation of online SIRS in Hospitals in the District of Kediri.

\section{The Influence of Officers' Knowledge of Online SIRS Reporting at Hospitals in Kediri Regency}

Based on the results of the Logistic Regression analysis of knowledge variables on utilization shows that the p-value of $0.006<0.05$ then $\mathrm{H} 0$ is rejected and $\mathrm{H} 1$ is accepted so it is concluded that there is an influence of the knowledge of the officers on the implementation of SIRS online at Hospitals in Kediri Regency. Whereas based on cross tabulation it is known that almost half of respondents who have knowledge of the category are doing SIRS Online reporting with less categories as many as 47 respondents $(28.3 \%)$. Based on the Odds Ratio test results found that respondents with high knowledge have the possibility of reporting SIRS Online well also by $81 \%$.

According to researchers knowledge is the basis for someone to do things well and correctly. The relevance of knowledge in reporting SIRS Online is very important where if the officer has high knowledge, he will understand about the benefits and functions of the SIRS itself, which is beneficial for the community, patients and hospitals themselves. Whereas low knowledge will cause SIRS reporting to be less well implemented where officers assume that reporting through SIRS Online instead burdens officers. So that in this study it was found that there is an influence of officers' knowledge on the implementation of SIRS online at Hospitals in Kediri Regency.

\section{The Influence of Staff Reward Against Online SIRS Reporting at Hospitals in Kediri Regency}

Based on the results of the Logistic Regression analysis the reward variable for utilization shows that a p-value of $0.023<0.05$ then $\mathrm{H} 0$ is rejected and $\mathrm{H} 1$ is accepted so it is concluded that there is an effect of the employee reward on the implementation of online SIRS in Hospitals across Kediri Regency. Whereas based on cross tabulation it is known that almost half of respondents who have a 
high category reward do SIRS Online reporting with less categories as many as 57 respondents (34.3\%). Based on the results of the Odds Ratio test it was found that respondents with high rewards had the possibility of reporting SIRS Online well as well as $92.9 \%$.

According to researchers the provision of rewards or gifts for officers who report SIRS Online properly can increase the desire of the officers themselves to work harder, in this case the implementation of SIRS Online. Where if he does his job well he will get appreciation and will even get royalties from the services he does. So that it will increase the benefits he gets every month. So the researchers concluded that there was an effect of the reward of officers on the implementation of online SIRS in Hospitals in Kediri Regency.

\section{Effect of Sanctions on Hospitals Against Online SIRS Reporting at Hospitals in the District of Kediri}

Based on the results of the Logistic Regression analysis the sanctions variable towards utilization shows that the p-value of $0.016<0.05$ then $\mathrm{H} 0$ is rejected and $\mathrm{H} 1$ is accepted so it is concluded that there is an effect of the officer sanctions on the implementation of online SIRS in Hospitals of Kediri Regency. Based on the results of the cross tabulation, it is known that almost half of the respondents who get sanctions accordingly do SIRS Online reporting with less categories as many as 52 respondents $(31.3 \%)$. Based on the results of the Odds Ratio test it was found that respondents with appropriate sanctions had the possibility of reporting SIRS Online well as well as $59.5 \%$.

According to researchers, sanctions for hospitals that do not implement SIRS Online correctly will be able to influence the implementation of the program. Because if the hospital is not given sanctions, the hospital will ignore this because it considers it can add to the administrative burden of expenses that must be borne by the hospital in this case the procurement of goods and the addition of salary to run this program. So it is necessary to have sanctions in stages for the implementation of SIRS online. So that the researchers concluded that there was an effect of officer sanctions on the implementation of SIRS online at Hospitals in Kediri Regency.

\section{CONCLUSION}

1. Most respondents have moderate motivation as many as 91 respondents (54.8\%).

2. Most respondents have knowledge in the medium category of 112 respondents $(67.4 \%)$.

3. Most respondents have a high category reward of 93 respondents $(56.1 \%)$.

4. Most respondents have a discrepancy with the sanctions provided as many as 88 respondents $(56.3 \%)$.

5. Most respondents lacked in conducting SIRS Online reports as many as 141 respondents (85.3\%).

6. There is an influence of staff motivation on the implementation of online SIRS in Hospitals in Kediri Regency

7. There is an influence of officers' knowledge on the implementation of online SIRS in Hospitals in Kediri Regency.

8. There is an effect of officer reward on the implementation of online SIRS in Hospitals in Kediri Regency

9. There is an influence of officers' sanctions on the implementation of SIRS online at the Kediri Regency Hospital

\section{SUGGESTION}

1. For Respondents

It is expected that respondents can implement SIRS Online reporting properly and appropriately so that all hospital activities can be monitored properly.

2. For Further Researchers

It is hoped that further researchers will need to deepen and add more research on the factors that influence the motivation of officers in implementing SIRS online at hospitals.

3. For Educational Institutions

It is expected that educational institutions can use the results of this study as learning inputs in the factors that influence the implementation of online SIRS at Hospitals in Kediri Regency.

4. For Research Sites 
It is expected that hospitals that have not done SIRS Online will re-coordinate so that data can be synchronized with the center. And can make it easier for policy makers to supervise the hospital.

\section{ACKNOWLEDGMENTS}

I say thank you to the respondents who are willing to be respondents in this study.

\section{CONFLICT OF INTEREST}

\section{Nothing}

\section{REFERENCE}

Ministry of Health. (2011). Juknis Sistem Informasi Rumah Sakit, Jakarta: Kementrian Kesehatan Republik Indonesia.

Ministry of Health. (2011). Permenkes Nomor 1171 / Menkes/ Per/ VI/2011 tentang Sistim Informasi Rumah Sakit, Jakarta: Kementrian Kesehatan Republik Indonesia.

Ministry of Health. (2014), Permenkes Nomor 56 tahun 2014 tentang Klasifikasi dan Perizinan Rumah Sakit, Jakarta: Kementrian Kesehatan Republik Indonesia.

Putriah. (2013). Analisis Efektif Penerapan Sistem Informasi Rumah Sakit Revisi VI di Rumah Sakit Umum Bangkinang. Surabaya.

Ridwan, HR. (2011), Hukum Administrasi Negara. Jakarta: Raja Grafindo Persada.

Rivai, V., Fawzi, A. (2008). Performance Appraisal. Jakarta: PT. Raja Grafindo Persada.

Robbins, SP. (2008). Perilaku Manusia: Konsep Kontroversi Dan Aplikasi, Jakarta: PT. Prenhallindo.

Setiadi. (2007). Konsep dan Penulisan Riset Kesehatan. Yogyakarta: Graha Ilmu

Siagian, Sondang. (2012). Teori Koordinasi dan Aplikasinya, Jakarta: Rineka Cipta

Soeprihanto. (2010). Manajemen SDM dalam Publik dan Bisnis, Cetakan Kedua, Jakarta: Alfabeta. 2000.

Swarburg, RC. (2011). Hubungan Pemenuhan Kebutuhan Tenaga Kerja Dengan Motivasi Kerja, Jakarta: Buku Kedokteran EGC.

Uno, Hamzah, B. (2013). Teori Koordinasi dan Pengukurannya. Jakarta: Bumi Aksara.

Wibowo. (2010). Manajemen Kinerja Edisi 3, Jakarta: PT. Raja Grafindo Persada. 